\title{
Issue to the Legal Protection of the Use of the State Budget to Handling Covid-19
}

\author{
Soesi Idayanti \\ Universitas Pancasakti Tegal, Indonesia \\ soesi.idayanti@gmail.com
}

\begin{abstract}
The Covid-19 pandemic, which impacted the health, social, and economic sectors as a non-natural disaster, led the President to make efforts to handle it with state financial policies by stipulating Perpu Number 1 of 2020. Budget misuse during the Covid-19 pandemic should be punishable by the death penalty because carried out when the state is facing a precarious situation; however, in Perpu No.1/2020, the Government grants immunity rights state budget managers. This legal immunity needs to be studied as a standard-issue regarding the state budget to overcome the Covid-19 pandemic. This study aims to examine the pandemic's impact on state finances and how Government policies are in dealing with the Covid-19 pandemic. This study used a normative juridical approach with data obtained from the literature, and the results were analyzed qualitatively. The results showed that the Covid-19 pandemic resulted in the Government changing the output of the use of the state budget aimed at dealing with the pandemic and restoring the country's economic condition due to the pandemic; the legal solution is to stipulate Perpu Number 1 of 2020, which was then approved by the DPR and became Law Number 2 2020. At the technical, operational level, the Government has also issued various policy regulations as a followup to Law Number 2 of 2020, which is used as an effort to deal with precarious situations as a result of the Covid-19 pandemic, such as fiscal policy stimulus, taxes, social assistance, and policies. Adjustment of regional finances. The problem that was considered urgent due to the Covid-19 pandemic led the Government to stimulate immunity in Law Number 2 of 2020. However, this immunity is given following the principle of good faith for users of state finances
\end{abstract}

Keywords

covid-19; discretion; state finance; minister of social affairs

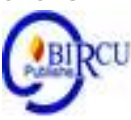

\section{Introduction}

Starting March 2020, the Indonesian Government is faced with the fact that the Covid-19 pandemic has claimed the lives of Indonesia's people. The number of victims exposed to Covid-19 increases from time to time, which is increasingly dangerous and threatens public health. This affects not only public health but also other sectors, including the economic sector, so that the Government is encouraged to act quickly, precisely, and precisely in the face of the Covid-19 pandemic. The Government is implementing steps to respond to the Covid-19 pandemic by using statutory authority, policies and regulations, actions of government agencies and officials, and the bureaucracy as a combination of policy implementing agencies (Juliani, 2020).

In dealing with the Covid-19 pandemic, the President took a policy and issued a government regulation to replace Law No.1 of 2020 (Perppu), which regulates large-scale handling and/or overcoming threatened electricity (Grediani, 2020). Coronavirus disease 
(Covid-19) National financial policy and financial system stability will endanger the national economy's strength and/or economic system on March 31, 2020.

Perppu No.1 / 2020 is stipulated as a juridical way of handling Covid-19 because it is proven that the Covid-19 pandemic impacts a slowdown in national economic growth and a decrease in national income and an increase in state spending and financing. Therefore, the Government needs to work hard to save national health and economy, with a focus on spending on health, social safety nets, and economic recovery, including affected businesses and communities (Sarip, 2020).

Economic growth is still an important goal in a country's economy, especially for developing countries like Indonesia. Economic growth must also be followed by positive changes in the context of improving the welfare and prosperity of the people who are mandated by the 1945 Constitution (Magdalena, 2020). Since both inflation and economic growth are not a new concept rather their relationships are waited still now as a debatable issue among macro-economists, policy makers, policy analysts, politicians and even the population itself by giving their own analysis by conduct a research and assumption based on the trend as before (Wollie, 2018).

At a time when the country is in a critical situation facing the Covid pandemic-19, social minister Juliari Batubara was arrested by the Corruption Eradication Commission for allegedly accepting bribes for the provision of social assistance, causing the country to suffer losses of 17 billion, corruption during this pandemic is important to note. , so that legal protection of state finances can be ensured that they are suitable for their use. From this incident, the question was asked to what extent the President's effectiveness in regulating the right to immunity in the Perppu No.1 of 2020, and what is the impact on the implementation of the state budget (APBN)?

Research conducted by the Ministry of Finance shows that the Covid-19 pandemic hurts the domestic economy, such as a decrease in public consumption and purchasing power, a decline in corporate performance, threats to banking and the financial sector, and 5 in terms of consumption and public purchasing power. Many workers have experienced a slip and even lost income, which affects the community's level of consumption and purchasing power, especially among the informal workers and daily workers. Because it is uncertain when this pandemic will end, most people are cautious in managing their financial expenses.

The social distancing policy was then changed to physical distancing and working from home or home, resulting in a decline in company performance and subsequent layoffs. Some companies even went bankrupt and finally chose to close their businesses. In the banking and finance sector, this outbreak has raised concerns about debt or credit repayment, which ultimately impacts the sustainability of bank performance. The Government usually adopts two policies to solve economic problems, namely fiscal policy and monetary policy. Fiscal policy is the Government's move to change the tax or expenditure system to overcome existing financial issues, and monetary policy is a policy formulated by the Central Bank (Bank Indonesia). Money can be saved.

From the explanation above, the problems to be discussed are: what is the impact of the Covid-19 pandemic on the use of the state budget, how the Government's legal policies face the Covid-19 pandemic. 


\section{Research Methods}

Research Type This research is library research (library research). Literature research explores literature or data sources obtained from books, books, and others with a direct or indirect relationship with this theme. This research seeks to study legal protection and the accuracy of the stipulation of Perpu number 1 of 2020, which is the basis for the state budget to overcome the Covid-19 pandemic (Hamzani, 2020).

This research approach uses a normative system, namely reviewing legal issues in a normative manner regarding whether it is allowed according to applicable law. The use of the normative approach aims to examine the appropriateness of the use of the state budget for handling Covid-19 based on Perpu number 1 of 2020 (Pratama, 2020) The research data is secondary data, the sources of legal research consist of primary and secondary legal materials. So the sources and types of research materials used in this research material include primary standard materials, namely binding standard materials, such as Government Regulation instead of Law Number 1 of 2020 concerning State Financial Policy and Financial System Stability for Handling the Corona Virus Pandemic Disease 2019 (Covid-19) and/or in the Context of Facing Threats that Endanger the National Economy and/or Financial System Stability and other relevant regulations. Secondary legal materials, in the form of seminar results or other scientific discoveries, even personal documents or views of legal experts as long as it relates to this research study's object. This can be in legal books, journals or legal research reports, the internet, and materials related to the issues discussed (Rahardjo, 2010).

Data processing using the descriptive analysis method means that the data used is a qualitative approach to primary and secondary data. The descriptive includes the content and positive legal structure, which is an activity carried out by the author to determine the content or meaning of legal rules that are used as references in solving legal problems that are the object of study. (Ali, 2009).

The data is analyzed qualitatively; in other words, that data analysis prioritizes the overall aspect and deepens it with the data in question, from the data that has been collected will be sorted to obtain articles containing legal rules governing state budget problems to deal with a pandemic Covid-19 (Rahmansyah, 2020). Following the character of qualitative research, the flow of thought in data analysis in this study is an inductive pattern, that is, the analysis begins with things of unique character, through legal principles in various laws and regulations that are directly related to or related to legal issues regarding the use of the state budget. To overcome the Covid-19 pandemic (Firdausy, 2020).

\section{Results and Discussion}

\subsection{Impact of the Covid-19 Pandemic on the Use of the State Budget}

The Covid-19 pandemic is urgently needed through the 2020 Perppu because the Covid-19 pandemic on health, economy, society, and other aspects will ultimately harm people's welfare. In the interpretation of Perppu No.1 / 2020, it can be said as follows: The Covid-19 pandemic has severely disrupted economic activity and affected the economies of most countries in the world, including Indonesia. In the 2020 State Budget (APBN) Posture, both in terms of state revenues, state spending, or financing, state fiscal and fiscal policies need to be responded to in response to the risk of the Covid-19 pandemic, including increased spending. To reduce health risks, protect the community and maintain 
business activities. Financial sector pressures impact the state budget (especially in financing) (Santosa, 2016).

The President issued Presidential Decree No. 4 of 2020 on March 20, 2020, which includes realigning the focus of activities, budget reallocation, and procurement of goods and services to accelerate Coronavirus disease processing 2019 (Covid-19). These matters are regulated by Presidential Decree No. 4 of 2020. Among them, priority refers to the existing budget allocation for accelerating Covid-19 processing (activity readjustment and budget redistribution), the method relates to the Covid-19 processing agreement from various ministries/agencies. / local governments and to accelerate the processing of Covid19. The operation plan for 19, determined by the Covid-19 Processing Acceleration Working Group, accelerates the focus of activities and budget reallocation through a budget revision mechanism and immediately submits a budget revision proposal to the Minister of Finance according to his / her authority; accelerating the procurement of goods and services through facilitation and expansion of access points following the law to support accelerated processing of Covid-19; 2020 Presidential Instruction Number 4 is a policy and regulation issued by the President to exercise the right to handle the technical field of the Covid-19 pandemic related to the budget available in the 2020 State Budget, regarding the fulfillment of PPE, emergency hospitals, medicines, and medical care. The need for supporting costs and others (Aulawi, 2020).

The President issued Perppu No. 1 concerning national fiscal policy and financial system stability in response to the 2019 Coronavirus Disease (COVID-19) pandemic and/or threats to economic stability and/or national financial system / 2020. Regarding Law Number 2 of 2020, which regulates the Perppu, concerning National Financial Policy and Financial System Stability (Covid-19) relating to the 2019 Coronavirus pandemic and/or endangering the economy and/or national system in the face of threats. Stable No. 1 Legal Finance in 2020 becomes law and is added as an integral part of this law. The law will come into effect on the issue date, namely May 18, 2020. The Government has taken extraordinary policies and steps to overcome the Covid-19 pandemic emergency's socioeconomic impact through various relaxation policies related to the implementation of the State Budget, especially increasing health spending and net spending. Social security, and economic recovery, and strengthening the powers of various institutions in the financial sector.

The implementation of state financial policies in handling the Covid-19 pandemic was carried out by changing the posture and/or details of the 2020 State Budget stipulated by Law Number 20 of 2019. State financial policies related to state revenue policies including policies in the field of taxation, state spending policies including policies in regional finance, and financing policies. State economic policies regulated in Perppu No.1 of 2020 include: Budgeting and financing, in the framework of implementing state financial policies, then based on Perppu No.1 of 2020, the Government has the authority to set a budget deficit limit, provided that it exceeds 3\% (three percent) of the Gross Domestic Product (GDP) during the handling of Corona Virus Disease 2019 (Covid-19) and/or to face threats that endanger the national economy and/or financial system stability no later than the end of the Fiscal Year 2022 (Pakpahan, 2020).

\subsection{Legal Policy for Handling the Covid-19 Pandemic}

Law as Social Control or social control is a form of implementation of legal certainty, so that laws and regulations that are carried out are properly implemented by the authorities and law enforcers. Legal changes must be able to overcome the gaps that arise which can interfere with public order and productivity. To prevent the Covid-19 outbreak, 
it is necessary to form a law as a social controller. The Covid-19 outbreak has brought changes to the movement of the economic structure of society. Emphasizing legal principles is needed to facilitate the formation of the economic structure of society. The enforcement of principles that are not following legal regulations will slow down creating the desired economy.

The country's fiscal policy in response to the Covid-19 pandemic was carried out by changing the status and/or details of the 2020 State Budget regulated in Law Number 20 of 2019. State fiscal policy related to state taxation policies, including policies in taxation and state spending policies, includes regional financial policies and financing policies in Perppu No.1 of 2020. In implementing national fiscal procedures, budget and financing are guided by Perppu No.1 of 2020. The Government has the right to set limits on the budget deficit, provided that the deficit exceeds GDP during the treatment period Virus Disease Corona in 2019. (GDP) 3\% (three percent) (COVID-19) and/or facing a threat to national economic stability and/or the financial system no later than the end of the 2022 fiscal year (Fahrika, 2020).

Since the 2023 fiscal year, the deficit will be returned to a maximum of $3 \%$ (three percent) of the Gross Domestic Product (GDP); and the deficit in number 1 will gradually be adjusted to the drought in number 2. Adjusting mandatory expenditure (mandatory expenditure) following the relevant laws and regulations; transfer budgets between organizational units, functions and/or plans, and take action so that payments become unavailability of APBN costs. Use or be sufficient, and use the procurement budget to determine the process and means of purchasing goods/services. From the excess account, educational contributions, and accumulated contributions, funds controlled by the state according to certain standards, funds managed by the Public Service Bureau, and/or derived from a reduction in the BUMN national capital participation fund (Ahsan, 2020).

Issuance of Government Securities and/or State Sharia Securities with specific objectives, especially in the context of the coronavirus pandemic (COVID-119) in 2061, by Indonesian banks, State-Owned Enterprises (BUMN), corporate investors, Denver, or Purchases by retail investors, determine the source of budget funds from within and outside the country, provide loans to save insurance companies, prioritize budget allocations for specific activities (re-focus), adjust allocations, and/or cut/postpone budget allocations to be transferred to various regions and rural funds with certain conditions provide grants to local governments, and/or facilitate the national financial sector mechanism and facilitate documents.

Regarding other provisions of the national fiscal policy, the Minister of Finance Regulation (including PMK Number 33 / PMK.010 / 2020 concerning Procedures for Providing Loans to the Government to Deposit Insurance Companies, PMK Number 38 / PMK.02 / 2020 Regarding the processing of the implementation of the coronavirus pandemic (Covid-19) and/or the threat of national fiscal policies that endanger the stability of the national economy and/or the financial system PMK Number 46 / PMK.07 / 2020 Under the influence of the epidemic (Covid-19) and the 2019 Coronavirus (Covid-19) disease pandemic, central government fund allocations for local governments are managed.

In the context of implementing regional financial sector policies, regional financial sector policies empower provincial governments to prioritize the use of budget allocations for specific activities (re-focus), change assignments, and use regional revenue and expenditure budgets.

The policies of the taxation department and the taxation sector include, among others, adjustments to the income tax rate of domestic corporate taxpayers and permanent establishments, the tax treatment of trading activities conducted through electronic 
systems, the timing of exercising rights and fulfilling tax obligations; and authorization of the Minister of Finance to provide customs facilities that are exempted from import duties or reduction or exemption of import duties in the context of handling emergencies and restoring and strengthening the national economy (Fitri, 2021). Transactions conducted through an electronic system are transactions made through a series of electronic devices and procedures. Adjustment of income tax rates for domestic corporate taxpayers and permanent establishments in the form of lowering the tax rate of Article 17 paragraph (1) $b$ of the Income Tax Law to 22\%, which applies to the 2020 tax year and the 2021 tax year; $20 \%$ to 2022 Effective for the fiscal year.

To support national fiscal policies and save the national economy, the National Economic Recovery Plan was implemented, and the Government implemented the National Economic Recovery Plan. The program aims to protect, maintain, and improve business actors' economic capacity from the physical and financial sectors to conduct business (Widiarseno, 2021). The national economic recovery plan is implemented through state capital participation, government funds and/or investment, and guarantee activities in the Government's agenda (Kusuma, 2021). State participation is carried out through appointed SOEs. Placement of government funds and/or investment can be done directly by the Government and/or through financial institutions, investment managers and/or other appointed institutions. The guaranteed plan can be implemented now by the Government and/or through one or several designated guarantee business entities. The national economic recovery program's implementation is regulated by Government Regulation, Government Number 23 of 2020 (Feranika, 2020).

The implementation of the national fiscal policy, the federal fiscal policy's performance, and the steps described in Articles 2 to 11 are carried out on the premise of proper compliance with good governance. In the framework of implementing the state's fiscal policies and procedures as referred to in Articles 2 to 11, details of changes in the posture and/or state revenue and expenditure budget (APBN) are subject to the Presidential Regulation (Perpres 54/2020). Or use it as a basis.

Report: The Government must report in the Central Government's financial statements regarding the use of the budget in the process of implementing national fiscal policies and procedures as referred to in Articles 2 to 12 of the Perpu 1/2020. Issued by the Government and/or KSSK member institutions in the process of implementing national tax policies, including, among others, taxation policies and state expenditures. These policies include regional financial policies, financing policies, financial system stabilization policies, and national economic recovery plans, which are part of the economic costs of saving the economy from crisis, not state losses (Hadiwardoyo, 2020).

On. Paragraph (2) The Perppu for the Termination of Transaction Regulation further states that KSSK members, KSSK secretaries, members of the KSSK secretariat, and officials or employees of the Ministry of Finance, Bank Indonesia, the Financial Services Authority, as well as the Deposit Insurance Corporation, and other officials related to the implementation of Government Regulations instead of this law, it cannot be prosecuted both civil and criminal if the task is based on good faith and following the provisions of statutory regulations (Jahrir, 2021). Paragraph (3) further states that all actions, including decisions made based on this Government Regulation instead of Law, are not the object of a lawsuit that can be submitted to the State Administrative Court (Disantara, 2020).

For officials in Article 27 of the PERPPU1 / 2020 Law, the aspect of robust legal immunity is constitutionally contrary to Article 28D of the 1945 Constitution of the Republic of Indonesia, which states that "everyone has the right to before facing recognition of fair and equal treatment, guarantee, protection, and legal certainty. "The 
provisions of Article 28D provide legal assurance and lawful enjoyment for all parties, including members of the KSSK secretariat, members of the KSSK secretariat, and officials or employees of the Ministry of Finance, Bank Indonesia, the Financial Services Authority, and the Deposit Insurance Corporation. The same treatment, and other officials regarding the implementation of PERPPU (Gunawan, 2020).

Then, the statement of Article 27 PERPPU is also contrary to Article 28I paragraph (1) of the 1945 Constitution of the Republic of Indonesia. "The right to be recognized as an individual before the law and the right not to be prosecuted according to retrospective law are human rights it cannot be reduced under any circumstances", and Article 27 paragraph (1) of the 1945 Constitution of the Republic of Indonesia: "All citizens enjoy the same position in law and Government, and must uphold legal and Government rights without exception. In other words, PERPPU officials/implementers cannot be sued for any reason, contrary to the principle of judicial independence, the focus of checks and balances (Sugiri, 2021).

The super body's origin denies the constitutional principle adhered to by the 1945 Constitution, which does not allow power to exceed the 1945 Constitution (limited Government). Therefore, ideally, the Indonesian Parliament rejects PERRPU because it is on the same basis. That is, impunity in implementing national financial management, the Democratic Republic rejects "Government Regulation." It replaces the "Financial System Safety Net No. 4 of 2008 " to avoid or even avoid the possibility of abuse of power by the executor to the maximum (Umar, 2020).

On the other hand, some people think that if you see an emergency, you can be exempted from this legal exemption. Of course, you have to pay attention to some of the principles and principles of emergency law, namely the principle of need and selfprotection; Besides that, according to Spinoza. According to this view, the stability of a country is the stability of the country, and the good of a country is its stability. This principle shows that a country really needs to take the necessary steps (regardless of whether it takes a policy) to protect and maintain its integrity. Some people even assert that something illegal can become legal (Mahardika, 2020).

Provisions of Article 27 of Perppu No. 1 of 2020 provides a guarantee to the Government that all actions and/or decisions are taken in dealing with the Covid-19 pandemic are related to costs, even if losses or reductions in state finances are incurred, also not national losses, because they are used to save the economy. Crisis. Therefore, filing an administrative lawsuit is not the purpose of the case (Indayani, 2020). Government officials involved in implementing Perppu No.1 / 2020 will not be subject to civil or criminal charges if they carry out their good faith duties and follow statutory regulations. According to Article $24 \mathrm{f}$ of Law no. 30 of 2014, good faith is based on honest motives and decisions and/or actions taken following the AUPB (General Principles of Good Governance). The AUPB is those that fulfill the formulation of Article 10 of Law Number 30 of 2014 concerning Government Administration, namely legal certainty, usefulness, impartiality, accuracy, not abusing authority, openness, public interest, and good service (Adiyana, 2020).

Article 28 of Perpu Number 1 of 2020 states that when this Government Regulation instead of Law comes into effect, there are several provisions related to state fiscal policy, including that: 1). Article 12 paragraph (3) and its explanations, Article 15 paragraph (5), Article 22 paragraph (3), Article 23 paragraph (1), Article 27 paragraph (3), and Article 28 paragraph (3) in Law Number 172003 on State Finance (State Gazette of the Republic of Indonesia Year 2003 Number 47, Supplement to the State Gazette of the Republic of Indonesia Number 4286). 
Article 3 paragraph (3) of Law Number 1 of 2004 concerning State Treasury (State Gazette of the Republic of Indonesia of 2004 Number 5, Supplement to State Gazette of the Republic of Indonesia Number 4355); Article 11 paragraph (22), Article 40, Article 42, and Article 46 of Law Number 20 of 2019 concerning the State Budget for the Fiscal Year 2020 (State Gazette of the Republic of Indonesia of 2019 Number 198, Supplement to the State Gazette of the Republic of Indonesia Number 6410), is declared invalid as long as it relates to state financial policies for handling the spread of Covid-19 and/or in the context of facing threats that endanger the national economy and/or financial system stability based on this Perppu (Sianipar, 2020).

The Government, in this case, the Minister of Finance, has followed up by issuing several regulations, including Regulation of the Minister of Finance Number 39 / PMK.02 / 2020 concerning Procedures for Budget Revision for Fiscal Year 2020, Regulation of the Minister of Finance Number 43 / PMK.05 / 2020 concerning the Mechanism for Implementing the Budget. On the State Budget Burden in Handling the Covid-19 Pandemic. Perppu No.1 / 2020 is an implementation of the President's right to exercise discretionary powers to handle the Covid-19 pandemic, which was later approved by the DPR as Law Number 2 of 2020 and promulgated on May 18, 2020. In addressing the Covid-19 pandemic, the Government also issued various laws and regulations, including Presidential Instruction Number 4 of 2020 and other policy regulations, to facilitate government officials' discretionary authority in the operational, technical realm the handling of the Covid-19 pandemic.

\section{Conclusion}

According to Article 22 paragraph (1) of the 1945 Constitution, the change of people's status by law (Perppu) by the Government is a discretionary authority granted by the constitution and is the President's right. As part of the hierarchy of rules and regulations combined with policies and regulations, as a technical basis for handling the Covid-19 pandemic, of course, it must be supported by the bureaucracy as policy implementer. The President and government officials' policies are strategic policies in the form of decisions and/or actions to resolve specific urgent problems that require immediate attention. Legal immunity is seen as an alternative because state finances in an emergency need a quick response. Still, ideally, it is adjusted to the principles of good faith and good governance.

\section{References}

Adiyanta, F. S. (2020). Fleksibilitas Pajak sebagai Instrumen Kebijaksanaan Fiskal untuk Mengantisipasi Krisis Ekonomi sebagai Akibat Dampak Pandemi Covid19. Administrative Law \& Governance Journal, 3(1), 162-181.

Ahsan, M. (2020). The Influence of Corporate Internal and External Factors on BUMN Share Prices: A Case Study in 12 BUMNs. Asian Journal of Economics, Business and Accounting, 9-21. Doi:10.9734.

Ali, Z. (2009). Metode Penelitian Hukum. Jakarta: Sinar Grafika.

Aulawi, A. (2020). Penerbitan Peraturan Pemerintah Pengganti Undang-undang Nomor 1 Tahun 2020 Sebagai Strategi Kebijakan Pajak Pemerintah Indonesia Dalam Menghadapi Dampak Pandemi Covid-19 Terhadap Keuangan Negara. Progress: Jurnal Pendidikan, Akuntansi dan Keuangan, 3(2), 110-132. doi:10.47080.v3i2.936

Disantara, F. P. (2020). Aspek Imunitas Dalam Penanganan Corona Virus Disease 2019. Istinbath: Jurnal Hukum, 17(1), 65-82. doi:10.32332.v17i1.2049 
Fahrika, A. I. (2020). Dampak pandemi covid 19 terhadap perkembangan makro ekonomi di indonesia dan respon kebijakan yang ditempuh. Jurnal Inovasi, 12(2), 206-213.

Feranika, A. \&. (2020). Strategi Kebijakan Fiskal Terhadap Output dan Inflasi pada Perekonomian Indonesia dalam Menghadapi Dampak Virus Covid 19. Business Innovation and Entrepreneurship Journal, 2(3), 146-152. doi:10.29264.v16i2.8255

Firdausy, B. M. (2020). Menakar Kualitas Kepemimpinan Presiden Jokowi Di Tengah Wabah Pandemi Covid-19. KAIS Kajian Ilmu Sosial, 1(2), 80-90.

Fitri, W. (2021). Dampak Penyebaran Covid-19 terhadap Dunia Pendidikan dan Sanitasi Di Indonesia. Syntax, 3(1), 56-72.

Grediani, E. (2020). Mengungkap fenomena anggaran perubahan dan partisipasi masyarakat akibat Pandemi Covid 19. Imanensi: Jurnal Ekonomi, Manajemen, dan Akuntansi Islam, 5(2), 69-78.

Gunawan, S. R. (2020). Analisis Kekebalan Hukum Bagi Komite Stabilitas Sistem Keuangan (KSSK) Berdasarkan Undang-Undang Republik Indonesia Nomor 2 Tahun 2020 Tentang Penetapan Peraturan Pemerintah Pengganti Undang-Undang Nomor 1 Tahun 2020 Tentang Kebijakan Keuangan Negara Dan. JISIP (Jurnal Ilmu Sosial dan Pendidikan), 44-58. doi:10.36312v4i4.1511

Hadiwardoyo, W. (2020). Kerugian Ekonomi Nasional Akibat Pandemi Covid-19. BASKARA: Journal of Business \& Entrepreneurship, 2(2), 83-92. doi:10.24853

Hamzani, A. I. (2020). Peningkatan kapasitas sumber daya manusia dengan pemahaman literasi hukum. Madani, 56-61. doi:10.33292.v1i2.3.

Indayani, S., \& Hartono, B. (2020). Analisis Pengangguran Dan Pertumbuhan Ekonomi Sebagai Akibat Pandemi Covid-19. Jurnal Perspektif, 18(2), 201-208.

Jahrir, A. S., Al Qadri, M. I., Nurfadilah, N., Wahyu, M. S., Syahria, S., Amiruddin, A., \& Rahmawati, R. (2021). Pengaruh Penggunaan Bahasa dalam Spanduk Lockdown Wilayah Terhadap Perilaku Sosial Masyarakat Pada Masa Pandemi Covid-19 di Kota Makassar. Panrita: Jurnal Bahasa dan Sastra Daerah serta Pembelajarannya, 2(1), 18-27.

Juliani, H. (2020). Kebijakan Fiskal: Anggaran Belanja Negara Untuk Perlindungan Sosial Dalam Penanganan Pandemi Covid 19. Administrative Law and Governance Journal, 3(4), 595-516.

Kusuma, E. D. (2021). Penerapan Sanksi Pelanggar Physical Distancing Dan Penggunaan Masker Berdasarkan Perwali Batu Nomor 78 Tahun 2020. Dinamika: Jurnal Ilmiah Ilmu Hukum, 27(6), 876-889.

Mahardika, A. G. (2020). Potensi Penyimpangan Hukum Dalam Peraturan Pemerintah Pengganti Undang-Undang Nomor 1 Tahun 2020. Jurnal Hukum IUS QUIA IUSTUM, 27(2), 264-284. doi:10.20885

Magdalena, S., and Suhatman, R. (2020). The Effect of Government Expenditures, Domestic Invesment, Foreign Invesment to the Economic Growth of Primary Sector in Central Kalimantan. Budapest International Research and Critics Institute-Journal (BIRCI-Journal). P. 1692-1703.

Marbun, S. d. (1987). Pokok-pokok Hukum Administrasi Negara. Yogyakarta: Liberty.

Pakpahan, A. K. (2020). Covid-19 Dan Implikasi Bagi Usaha Mikro, Kecil, Dan Menengah. Jurnal Ilmiah Hubungan Internasional, 59-64. doi:10.26593

Pratama, E. A. (2020). Business Ethics And Legal Liability In The Management Of StateOwned Enterprises. Journal of Critical Reviews, 7(15), 1401-407. Retrieved from http://www.jcreview.com/?mno=22413.

Rahardjo, S. (2010). Sosiologi Hukum Perkembangan Metode dan Pilihan Masalah. Yogyakarta: Genta Publishing. 
Rahmansyah, W., Qadri, R. A., Sakti, R. R. A., \& Ikhsan, S. (2020). Pemetaan Permasalahan Penyaluran Bantuan Sosial Untuk Penanganan Covid-19 Di Indonesia. JURNAL PKN (Jurnal Pajak dan Keuangan Negara), 2(1), 90-102.

Ridwan, H. (2013). Hukum Administrasi Negara. Jakarta: Raja Grafindo.

Santosa, D. H. (2016). Penggunaan Asas Diskresi dalam Pengambilan Keputusan. eJurnal Kemenkeu, 23-41. Retrieved from http://www.bppk.kemenkeu.go.id/publikasi/artikel/ 418-artikel-softcompetency/23181-

Sarip, S. S. (2020). Dampak Covid-19 Terhadap Perekonomian Masyarakat Dan Pembangunan Desa. Al-Mustashfa: Jurnal Penelitian Hukum Ekonomi Syariah, 5(1), 10-20. doi:10.24235.

Sianipar, G. A. (2020). Pemeriksaan Keuangan Negara pada Masa Pandemi Covid-19. Jurnal Sekuritas (Saham, Ekonomi, Keuangan dan Investasi, 4(1), 34-42. doi:10.32493v4i1.6392.

Sugiri, D. (2021). Perlakuan Akuntansi Belanja Tak Terduga pada Pemerintah Daerah Akibat Pandemi Covid-19. Jurnal Ilmiah Akuntansi dan Keuangan, 10(1), 58-68.

Syahrin, A. (2003). Pengaturan Hukum dan Kebijakan Pembangunan Perumahan dan Pemukiman Berkelanjutan. Medan: Pustaka Bangsa.

Tjandra, W. R. (2008). Hukum Administrasi Negara. Yogyakarta: Penerbit Universitas Atmajaya.

Umar, K. (2020). Pasal Imunitas Undang-Undang 'Corona'dan Kewenangan Badan Pemeriksa Keuangan Dalam Menetapkan Kerugian Negara. El-Iqthisadi: Jurnal Hukum Ekonomi Syariah Fakultas Syariah dan Hukum, 2(1), 114-129. Retrieved from http://103.55.216.56/index.php/iqthisadi/article/view/14044.

Widiarseno, D. (2021). Implementasi Permendes No. 6 Tahun 2020 Dalam Prioritas Penggunaan Dana Desa Tahun 2020 Di Desa Jambeyan (Doctoral dissertation, Universitas Islam Majapahit).

Wollie, G. (2018). The Relationship between Inflation and Economic Growth in Ethiopia. Budapest International Research and Critics Institute-Journal (BIRCI-Journal). P. 264-271. 